\title{
TAHAPAN PEMECAHAN MASALAH DENGAN DIAGRAM BAR UNTUK MENYELESAIKAN SOAL CERITA
}

\author{
Wiworo \\ PPPPTK Matematika, Jl. Kaliurang Km. 6, Sleman; percussionline@yahoo.com
}

\begin{abstract}
Abstrak. Soal cerita masih menjadi salah satu penyebab kesulitan siswa dalam belajar matematika. Empat tahapan pemecahan masalah yang disarankan Polya adalah: (1) memahami masalah, (2) merencanakan strategi, (3) melaksanakan strategi, dan (4) mengecek dan menafsirkan hasil. Salah satu strategi yang mendapat perhatian khusus adalah membuat diagram. Model diagram bar merupakan satu bentuk representasi diagram yang dapat membantu siswa menyelesaikan soal cerita. Penggunaan diagram bar dalam menyelesaikan soal cerita dapat menjadi strategi bagi siswa untuk menjembatani transisi dari memahami masalah dan membuat ekspresi matematis. Proses pembuatan model diagram bar merepresentasikan visualisasi informasi yang sudah diketahui dan yang belum diketahui serta membantu mengidentifikasi bagaimana informasi-informasi tersebut dapat digunakan untuk menyelesaikan masalah. Tulisan ini membahas tentang tahapan-tahapan pemecahan masalah menggunakan diagram bar untuk menyelesaikan soal cerita.
\end{abstract}

Kata Kunci-soal cerita, tahapan pemecahan masalah, diagram bar.

\section{PROBLEM SOLVING STAGES USING BAR DIAGRAM TO SOLVE WORD PROBLEMS}

\begin{abstract}
Word problems are still one of the causes of students' difficulties in learning mathematics. The four stages of problem solving suggested by Polya are: (1) understanding the problem, (2) planning a strategy, (3) implementing the strategy, and (4) checking and interpreting the results. One of the strategies to solve word problems that can be applied is by making diagram. The bar diagram model is a form of visual representation that can help students to solve word problems. The use of bar diagram in solving word problems can be a strategy for students to bridge the transition from understanding problems and making mathematical expressions. The process of creating a bar diagram model represents a visualization of known and unknown information and helps to identify how this information can be used to solve the problems. This paper discusses problem solving stages using bar diagram to solve word problems.
\end{abstract}

Keyword-word problems, problem solving stages, bar diagram.

\section{Pendahuluan}

Kemampuan menyelesaikan soal cerita (word problem) dipandang sebagai komponen kunci dalam belajar matematika (NCTM, 2000). Soal cerita tidak hanya berpotensi untuk memotivasi siswa, mengembangkan konsep dan keterampilan matematika yang bermakna, akan tetapi juga mengembangkan keterampilan untuk menerapkan matematika secara efektif dalam aktivitas sehari-hari (Verschaffel, 2000; Boaler, 1993; Hiebert, 1996; dalam Cheng, 2015). Soal cerita didefinisikan sebagai deskripsi tekstual dari situasi ketika pertanyaan matematis dapat dikontekstualisasikan (Verschaffel, dalam Cheng, 2015). Soal cerita adalah situasi ketika model matematis dapat diterapkan 
untuk merepresentasikan kuantitas-kuantitas dan hubungan-hubungan yang terdapat pada teks dan untuk mencari solusi dari pertanyaan yang diberikan (Nortveldt, 2001; dalam Cheng, 2015). Soal cerita masih menjadi salah satu penyebab kesulitan siswa dalam belajar matematika (Bryant, 2000; dalam Cheng, 2015). Terdapat empat klasifikasi kemampuan berbeda dalam menyelesaikan soal cerita dan masing-masing kemampuan dapat diselidiki untuk menjelaskan aspek apa saja dalam langkah menyelesaikan soal cerita yang menjadi penyebab kesulitan siswa. Empat kemampuan tersebut adalah: (1) kemampuan membaca masalah, (2) kemampuan menyiapkan masalah sehingga komputasi yang diperlukan siap untuk dijalankan, (3) kemampuan untuk melakukan komputasi yang diperlukan, dan (4) kemampuan untuk mengintegrasikan membaca, menafsirkan masalah, dan komputasi ke dalam solusi menyeluruh dari soal cerita (Ballew, 1982). Terdapat dua kelompok besar soal cerita, yaitu masalah aritmetika (arithmetic problem) dan masalah aljabar (algebraic problem). Masalah aritmetika melibatkan hasil-kuantitas tidak diketahui, adapun masalah aljabar melibatkan awal-kuantitas tidak diketahui (Khng, 2009). Perbedaan mendasar antara masalah aritmetika dan masalah aljabar adalah pada masalah aritmetika terdapat hubungan yang mudah ditemukan antara kondisi yang diketahui dan yang tidak diketahui, diistilahkan dengan connected. Adapun pada masalah aljabar adalah disconnected (Fong, 2005).

Empat tahapan pemecahan masalah yang disarankan Polya adalah: (1) memahami masalah, (2) merencanakan strategi, (3) melaksanakan strategi, dan (4) mengecek dan menafsirkan hasil (Polya, 2004). Salah satu strategi yang mendapat perhatian khusus adalah membuat diagram (Fong, 2005). Membuat diagram disarankan sebagai langkah awal dalam memahami masalah (Larson, 1985; dalam Gani, 2019). Ketika guru menggunakan diagram untuk memperoleh gambaran mental yang sesuai, siswa diketahui akan menampilkan kinerja yang lebih baik dalam situasi pemecahan masalah matematis (Yancey, 1989; dalam Gani, 2019). Representasi diagram adalah satu cara memahami masalah dalam penyelesaian soal cerita. Model diagram bar merupakan satu bentuk representasi diagram yang dapat membantu siswa menyelesaikan soal cerita (Gani, 2019). Penggunaan diagram bar dalam menyelesaikan soal cerita dapat menjadi strategi bagi siswa untuk menjembatani transisi dari memahami masalah dan membuat ekspresi matematis (Gani, 2019). Penelitian lain menunjukkan bahwa penggunaan diagram bar dalam menyelesaikan soal cerita merupakan cara luar biasa bagi siswa untuk mengorganisasikan cara berpikir, secara nyata menunjukkan ke siswa elemenelemen dari soal cerita dan membantu siswa memahami soal cerita dengan cara yang paling mendasar (Thirunavukkarasu, 2017). Diagram bar tidak hanya menjadi sarana siswa dalam menyelesaikan masalah matematis, akan tetapi juga membantu siswa dalam representasi simbolis yang menjadi andalan dalam penalaran aljabar (Thirunavukkarasu, 2017). Model diagram bar bersesuaian dengan pengembangan tahapan ikonik, ketika siswa mulai merepresentasikan konsep matematis dengan cara yang lebih abstrak melalui representasi piktorial (Hofer, 2015). Model diagram bar menjadi penghubung antara masalah dunia nyata dan bentuk matematisnya dan dapat menjembatani celah antara pengalaman matematis konkrit dan representasi abstrak dengan memberikan tahapan piktorial/ikonik (Spencer, 2015). Apabila guru 
membelajarkan siswa untuk menggunakan diagram bar sebagai pendekatan visual dalam menyelesaikan masalah matematis melalui petunjuk-petunjuk yang jelas, hal ini akan meningkatkan kemampuan pemecahan masalah siswa (Garzon, 2021).

Tujuan dari membuat diagram bar bukan untuk membuat siswa mengikuti aturanaturan tertentu, melainkan untuk lebih memahami konsep dan menyusun strategi untuk menemukan solusi dari masalah (Thirunavukkarasu, 2014). Membuat model piktorial berupa diagram bar sebagai representasi dari masalah sangat berperan penting dalam memahami masalah dan proses solusinya (Kho, 2014). Proses pembuatan model diagram bar merepresentasikan visualisasi informasi yang sudah diketahui dan yang belum diketahui serta membantu mengidentifikasi bagaimana informasi-informasi tersebut dapat digunakan untuk menyelesaikan masalah (Clark, 2017). Metode model dengan diagram bar mensyaratkan siswa untuk bekerja dengan tiga bentuk representasi yang berbeda, yaitu teks, piktorial, dan ekspresi numeris (Fong, 2009). Metode model diagram bar bukan merupakan algoritma, tetapi dibangun di atas pengetahuan siswa terhadap hubungan antara bagian-keseluruhan antar bilangan (Fong, 2009). Metode ini juga berperan sebagai jembatan untuk mendukung siswa SD dan SMP untuk mempersiapkan belajar aljabar (Yeo, 2019). Metode model dengan diagram bar dapat meningkatkan pengembangan berpikir aljabar dan dapat menyederhanakan saat transisi ketika mulai bekerja dengan variabel (Englard, 2010). Siswa yang belum mempunyai pengetahuan formal tentang aljabar memperoleh alat untuk mengonstruksi persamaan-persamaan dalam bentuk piktorial untuk menyelesaikan soal cerita yang menantang (Fong, 2004) dan dapat menggunakan penalaran untuk menyelesaikan secara konseptual berbagai soal cerita yang menantang (Beckmann, 2004). Penggunaan diagram bar secara efektif dapat membantu siswa untuk meningkatkan nilai matematikanya dan untuk menyelesaikan soal-soal HOTS (Puteh, 2017).

Bar yang digunakan berbentuk persegipanjang untuk merepresentasikan hubungan antara kuantitas numeris yang diketahui dan yang tidak diketahui dan untuk menyelesaikan masalah terkait kuantitas-kuantitas tersebut. Alasan pemilihan bentuk persegipanjang adalah karena lebih mudah dipartisi ke dalam unit-unit yang lebih kecil apabila dibandingkan dengan bentuk lain (Kaur, 2015). Apabila diagram bar digunakan untuk menyelesaikan masalah aritmetika, persegipanjang merepresentasikan masukanmasukan numeris tertentu. Adapun pada masalah aljabar, persegipanjang merepresentasikan variabel-variabel (Ng, 2008). Persegipanjang secara matematis menyatakan nilai dari yang tidak diketahui, siswa diharapkan dapat menentukan nilai tersebut dengan menganalisis hubungan antara persegipanjang-persegipanjang yang ada pada model (Fong, 2003).

Berdasarkan hal-hal tersebut tulisan ini akan membahas tentang tahapan-tahapan pemecahan masalah menggunakan diagram bar untuk menyelesaikan soal cerita kompleks. 


\section{Dasar Metode Model dengan Diagram Bar}

Terdapat tiga struktur berbeda dalam metode model dengan diagram bar, yaitu bagiankeseluruhan (part-whole), perbandingan (comparison), dan situasi sebelum-sesudah (before-after). Metode model ini diterapkan melalui proses sintesis dengan cara mengonstruksi model berdasarkan informasi yang diberikan pada masalah, selanjutnya menganalisis model untuk mengembangkan rangkaian langkah-langkah logis sampai dengan ditemukannya solusi dari masalah (Yee, 2009a).

\section{Model Bagian-Keseluruhan (Part-Whole Model)}

Model bagian-keseluruhan sering dinamakan model bagian-bagian-keseluruhan (partpart-whole model) (Kho, 2009). Model bagian-keseluruhan terdiri dari dua situasi, yaitu situasi penjumlahan-pengurangan dan situasi perkalian-pembagian (Yee, 2009a).

\section{Situasi penjumlahan-pengurangan}

Terdapat hubungan kuantitatif diantara tiga kuantitas, yaitu keseluruhan dan dua bagian (Kho, 2009). Keseluruhan dibagi ke dalam dua atau lebih bagian.

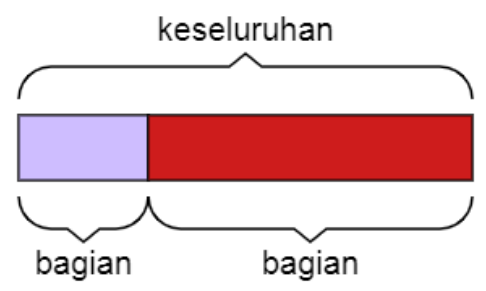

Apabila bagian-bagian diketahui kuantitasnya, keseluruhan dapat ditentukan nilainya dengan cara menjumlahkan.

$$
\text { bagian }+ \text { bagian }=\text { keseluruhan }
$$

Apabila keseluruhan dan satu bagian diketahui kuantitasnya, bagian lain yang tidak diketahui dapat ditentukan nilainya dengan cara mengurangkan.

$$
\text { keseluruhan }- \text { bagian }=\text { bagian }
$$

Situasi penjumlahan-pengurangan

Terdapat hubungan kuantitatif diantara tiga kuantitas, yaitu keseluruhan, satu bagian, dan banyak bagian (Kho, 2009). Keseluruhan dibagi ke dalam sejumlah bagian yang sama.

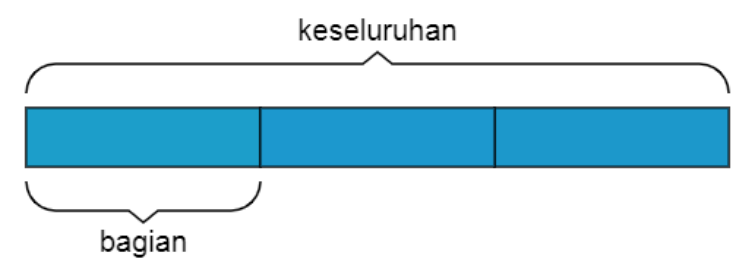


Apabila satu bagian dan banyak bagian diketahui, keseluruhan dapat ditentukan nilainya dengan cara mengalikan.

$$
\text { satu bagian } \times \text { banyak bagian }=\text { bagian }
$$

Apabila keseluruhan dan banyak bagian diketahui, satu bagian dapat ditentukan nilainya dengan cara membagi.

$$
\text { keseluruhan } \div \text { banyak bagian }=\text { satu bagian }
$$

Apabila keseluruhan dan satu bagian diketahui, banyak bagian dapat ditentukan nilainya dengan cara membagi.

$$
\text { keseluruhan } \div \text { satu bagian }=\text { banyak bagian }
$$

\section{Model Perbandingan (Comparisan Model)}

Model perbandingan menunjukkan hubungan antara dua atau lebih kuantitas ketika mereka dibandingkan (Yee, 2009a). Model perbandingan juga terdiri dari dua situasi, yaitu situasi penjumlahan-pengurangan dan situasi perkalian-pembagian (Kho, 2009).

\section{Situasi penjumlahan-pengurangan}

Dua kuantitas dibandingkan untuk menunjukkan seberapa satu kuantitas lebih besar atau lebih kecil dari kuantitas yang lain. Terdapat hubungan kuantitatif diantara tiga kuantitas, yaitu kuantitas lebih besar, kuantitas lebih kecil, dan selisih.

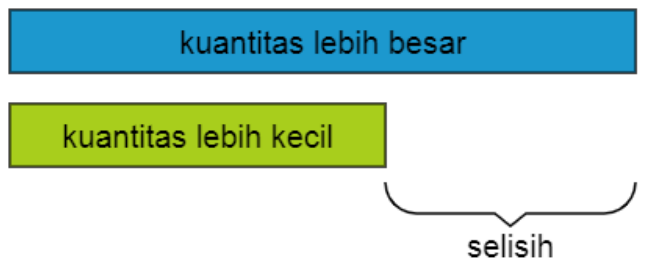

Selisih diperoleh dengan mengurangkan kuantitas lebih kecil dari kuantitas lebih besar.

$$
\text { kuantitas lebih besar }- \text { kuantitas lebih kecil }=\text { selisih }
$$

Apabila kuantitas lebih kecil dan selisih diketahui, kuantitas lebih besar dapat ditentukan nilainya dengan cara menjumlahkan.

$$
\text { kuantitas lebih kecil }+ \text { selisih }=\text { kuantitas lebih besar }
$$

Apabila kuantitas lebih besar dan selisih diketahui, kuantitas lebih kecil dapat ditentukan nilainya dengan cara mengurangkan.

$$
\text { kuantitas lebih besar }- \text { selisih }=\text { kuantitas lebih kecil }
$$




\section{Situasi perkalian-pembagian}

Dua kuantitas dibandingkan sedemikian hingga satu kuantitas adalah kelipatan dari yang lain. Terdapat hubungan kuantitatif diantara tiga kuantitas, yaitu kuantitas lebih besar, kuantitas lebih kecil, dan kelipatan.

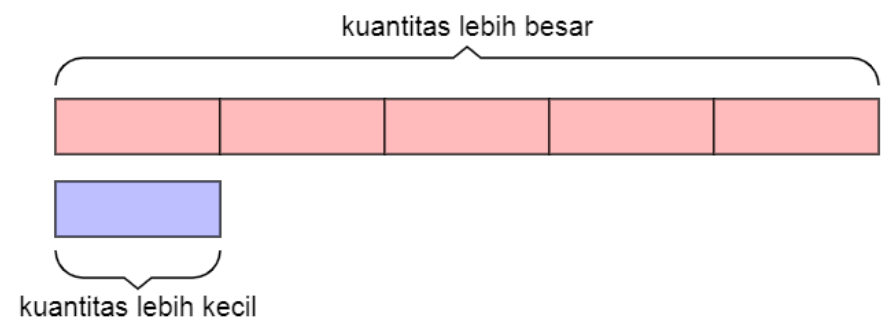

Kelipatan diperoleh dengan membagi kuantitas lebih besar dengan kuantitas lebih kecil.

$$
\text { kuantitas lebih besar } \div \text { kuantitas lebih kecil = kelipatan }
$$

Apabila kuantitas lebih kecil dan kelipatan diketahui, kuantitas lebih besar dapat ditentukan nilainya dengan cara mengalikan.

$$
\text { kuantitas lebih kecil } \times \text { kelipatan }=\text { kuantitas lebih besar }
$$

Apabila kuantitas lebih besar dan kelipatan diketahui, kuantitas lebih kecil dapat ditentukan nilainya dengan cara membagi.

$$
\text { kuantitas lebih besar } \div \text { kelipatan }=\text { kuantitas lebih kecil }
$$

\section{Model Perubahan Sebelum-Sesudah (Before-After Model)}

Model sebelum-sesudah menunjukkan hubungan antara nilai baru dari suatu kuantitas dan nilai awal setelah bertambah atau berkurang (Kho, 2009). Terdapat hubungan kuantitatif diantara tiga kuantitas, yaitu nilai awal kuantitas, perubahan (bertambah atau berkurang), dan nilai akhir kuantitas (Har, 2015).

\section{Situasi perubahan bertambah}

Sebelum

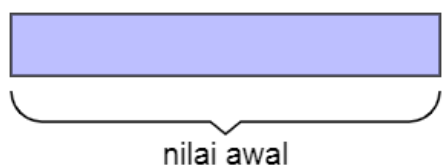


Sesudah

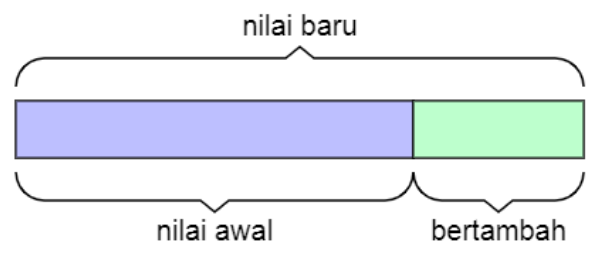

Situasi perubahan berkurang

Sebelum

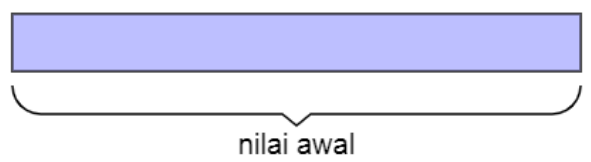

Sesudah

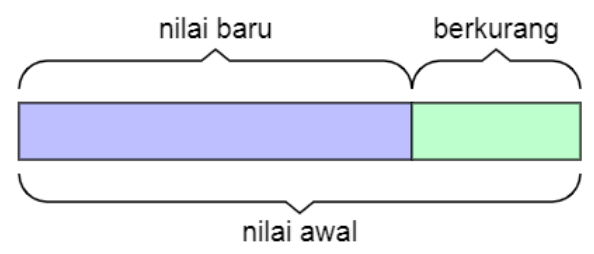

\section{Dasar Tahapan Pemecahan Masalah}

Empat tahapan pemecahan masalah yang disarankan Polya adalah: (1) memahami masalah, (2) merencanakan strategi, (3) melaksanakan strategi, dan (4) mengecek dan menafsirkan hasil. Langkah pada tahapan pertama adalah membaca masalah dengan cermat, merefleksi pertanyaan seperti apa yang diketahui, apakah informasi masalah sudah cukup, apakah masalah ini serupa dengan masalah lain yang pernah diselesaikan; dan memvisualisasikan serta mengorganisasikan informasi yang ada. Pada tahapan kedua langkah yang dilakukan adalah memikirkan strategi atau heuristik yang dapat membantu menyelesaikan masalah. Strategi yang dipilih dalam hal ini adalah membuat model atau diagram berupa diagram bar. Pada tahapan ketiga langkah yang dilakukan adalah melaksanakan strategi berupa membuat diagram bar diikuti dengan penalaran logis dan komputasi aritmetika yang sesuai. Langkah pada tahapan keempat adalah mengecek apakah hasil komputasi sudah sesuai dengan semua yang diketahui, menafsirkan hasil (Wuan, 2004).

Langkah-langkah metode model dengan diagram bar memfasilitasi proses pemecahan masalah yang disarankan Polya (Kho, 2009).

Langkah pertama.

Siswa mengonstruksi model untuk merepresentasikan masalah. Model ini membantu siswa memahami situasi dari masalah dan hubungan-hubungan kuantitatif yang ada. 
Langkah kedua.

Model memungkinkan siswa untuk menyusun rencana memecahkan masalah. Pada soal cerita satu langkah yang cukup diselesaikan dengan satu operasi aritmetika dasar (Reed, 1999), model membantu siswa menentukan operasi aritmetika yang digunakan untuk memecahkan masalah (Kho, 2009). Pada soal cerita dua langkah atau banyak langkah yang harus diselesaikan dengan kombinasi dari beberapa operasi aritmetika dasar (Reed, 1999), model membantu siswa mengindentifikasi langkah-langkah antara atau memformulasikan barisan langkah-langkah untuk memecahkan masalah (Kho, 2009).

Langkah ketiga.

Siswa melakukan perhitungan aritmetika untuk menjawab pertanyaan yang diberikan.

Langkah keempat.

Siswa mengevaluasi dan mengecek apabila jawaban memenuhi data-data yang diketahui dari masalah.

\section{Tahapan Pemecahan Masalah pada Soal Cerita}

Soal cerita yang dapat diselesaikan dengan metode diagram bar dapat berupa soal cerita sederhana sampai soal cerita kompleks dengan materi mulai dari bilangan cacah, pecahan, rasio, persentase, sampai dengan masalah aljabar (Kho, 2009).

Berikut diberikan beberapa contoh soal cerita dan tahapan pemecahan masalahnya dengan menggunakan strategi membuat diagram bar.

\section{Soal cerita 1:}

Yoga mempunyai tiga bilangan berbeda. Apabila setiap dua bilangan dipasangkan kemudian dijumlahkan akan diperoleh hasil berturut-turut 49,57, dan 64 . Tentukan ketiga bilangan tersebut.

\section{Tahapan pemecahan masalah:}

\section{Memahami masalah:}

Jumlah dua bilangan terkecil adalah 49. Jumlah dua bilangan terbesar adalah 64. Jumlah bilangan terkecil dan terbesar adalah 57.

\section{Merencanakan strategi:}

Strategi pemecahan masalah yang akan digunakan adalah membuat diagram bar.

Melaksanakan strategi:

Masalah ini merupakan masalah bagian-keseluruhan dengan bagian menyatakan masing-masing bilangan yang dijumlahkan dan keseluruhan menyatakan hasil pejumlahan dua bilangan.

Diagram bar untuk memodelkan hubungan penjumlahan bilangan-bilangan tersebut adalah sebagai berikut.

Langkah pertama

Membuat diagram bar berikut yang menyatakan penjumlahan dari masing-masing pasangan dua bilangan. 
49

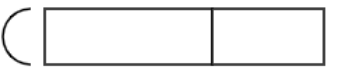

57

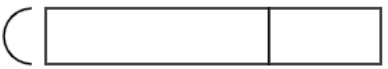

64

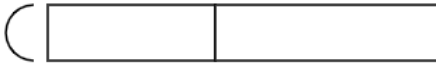

Langkah kedua

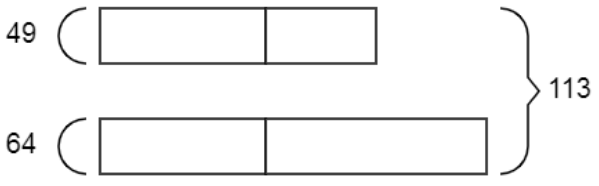

Langkah ketiga

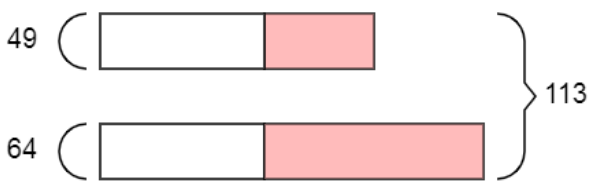

Dari langkah pertama dan dengan mengambil bagian diarsir pada langkah ketiga diperoleh

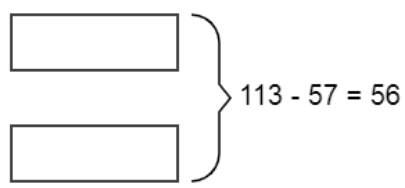

Dua unit bar menyatakan 56 , sehingga satu unit bar menyatakan $56 \div 2=28$.

Dari langkah ketiga diperoleh:

$49-28=21$

$64-28=36$

Mengecek dan menafsirkan hasil:

Bilangan terkecil 21, bilangan kedua 28, dan bilangan terbesar 36.

$21+28=49$

$21+36=57$

$28+36=64$

Dengan demikian ketiga bilangan tersebut adalah 21, 28, dan 36.

\section{Soal cerita 2:}

Hafiz, Aan, dan Afi masing-masing mempunyai sebuah bilangan. Bilangan Aan tiga kali bilangan Hafiz. Bilangan Afi lima kali bilangan Hafiz. Selisih antara bilangan Aan dan bilangan Afi adalah 70. Tentukan selisih antara bilangan Aan dan Hafiz.

\section{Tahapan pemecahan masalah:}

Memahami masalah:

Dari kalimat soal jelas bahwa bilangan terbesar adalah bilangan Afi, sedangkan bilangan terkecil adalah bilangan Hafiz.

Merencanakan strategi:

Strategi pemecahan masalah yang akan digunakan adalah membuat diagram bar.

Melaksanakan strategi: 
Masalah ini merupakan masalah perbandingan terkait dengan perkalian (dicirikan dengan frase "tiga kali bilangan" dan "lima kali bilangan").

Diagram bar untuk memodelkan hubungan ketiga bilangan tersebut adalah sebagai berikut.

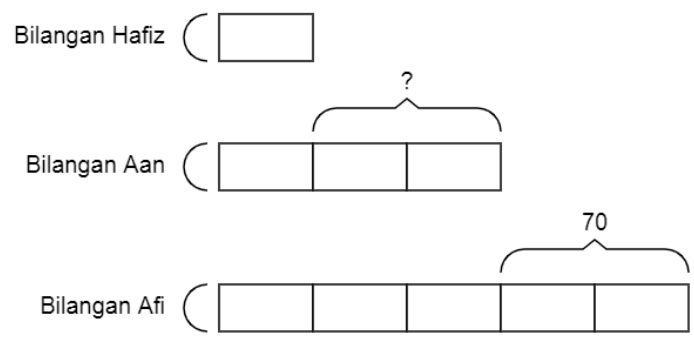

Perhitungan:

Pada model bilangan Afi diketahui bahwa dua unit bar menyatakan 70, sehingga satu unit bar menyatakan $70 \div 2=35$.

Pada bilangan Hafiz terdapat satu unit bar, sehingga bilangan Hafiz adalah 35.

Pada bilangan Aan terdapat tiga unit bar, sehingga bilangan Aan adalah $3 \times 35=105$.

Bilangan Hafiz 35, bilangan Aan 105, dan bilangan Afi $105+70=175$.

Mengecek dan menafsirkan hasil:

Bilangan Aan $3 \times 35=105$ (tiga kali bilangan Hafiz).

Bilangan Afi $5 \times 35=175$ (lima kali bilangan Hafiz).

Dengan demikian selisih antara bilangan Aan dan Hafiz adalah $105-35=70$.

\section{Soal cerita 3:}

Usia Laskar tiga tahun lebih muda dari usia Yafi. Usia Nanda tiga kali usia Yafi. Total usia Laskar dan Yafi 15 tahun kurangnya dari usia Nanda. Tentukan usia Nanda.

Tahapan pemecahan masalah:

\section{Memahami masalah:}

Dari kalimat soal jelas bahwa anak paling muda adalah Laskar, sedangkan anak paling tua adalah Nanda.

Merencanakan strategi:

Strategi pemecahan masalah yang akan digunakan adalah membuat diagram bar.

Melaksanakan strategi:

Masalah ini merupakan kombinasi masalah perbandingan terkait penjumlahan (dicirikan dengan frase "tiga tahun lebih muda" dan "15 tahun kurangnya") dan masalah perbandingan terkait perkalian (dicirikan dengan frase "tiga kali usia").

Diagram bar untuk memodelkan hubungan usia ketiga anak tersebut adalah sebagai berikut. 


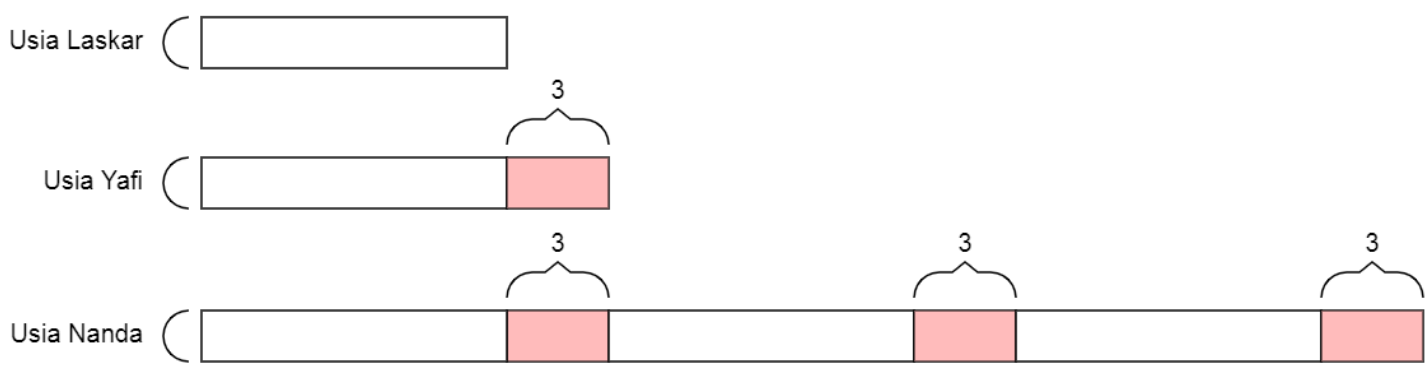

Berikutnya diagram bar disusun ulang sebagai berikut sehingga perbandingan total usia Laskar dan Yafi dengan usia Nanda lebih mudah untuk dipahami.

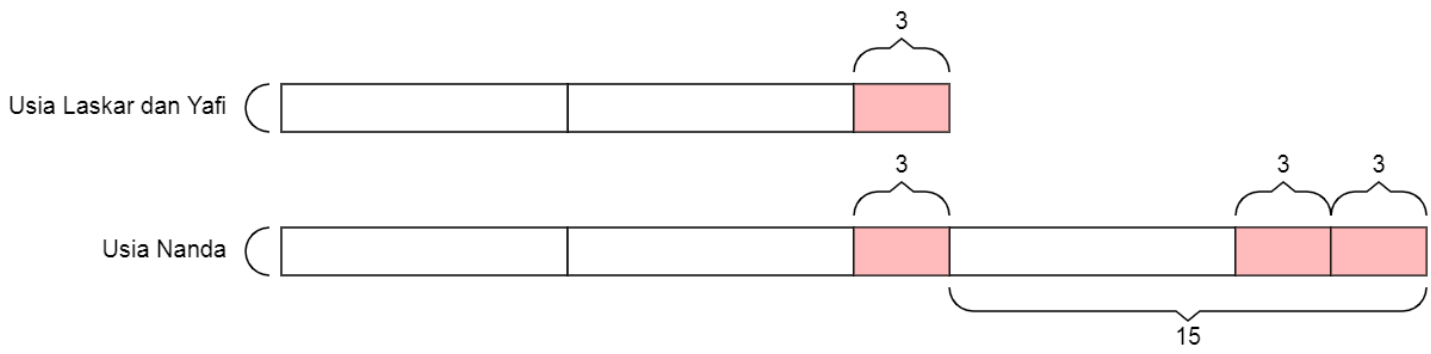

Perhitungan:

Dari diagram bar untuk usia Nanda diperoleh bahwa bar

menyatakan $15-2 \times 3=9$.

Sehingga usia Nanda berdasarkan model diagram bar adalah $3 \times 9+3 \times 3=36$.

Mengecek dan menafsirkan hasil:

Dari diagram bar untuk usia masing-masing diperoleh usia Laskar 9 tahun, usia Yafi $9+3=12$ tahun.

Total usia Laskar dan Yafi adalah $9+12=21$ tahun. Karena total usia mereka 15 tahun kurangnya dari usia Nanda berarti usia Nanda adalah $21+15=36$ tahun.

Dengan demikian usia Nanda 36 tahun.

\section{Soal cerita 4:}

Setelah memberikan $\frac{2}{5}$ dari seluruh koleksi pin brosnya kepada Ovi, Sekar masih mempunyai 72 buah pin. Tentukan banyak pin bros yang diberikan Sekar.

Tahapan pemecahan masalah:

Memahami masalah:

Sebanyak $\frac{2}{5}$ dari koleksi pin Sekar diberikan kepada Ovi. Koleksi pin tersisa adalah 72 buah.

Merencanakan strategi:

Strategi pemecahan masalah yang akan digunakan adalah membuat diagram bar.

Melaksanakan strategi:

Masalah ini merupakan masalah sebelum-sesudah dengan kondisi akhir diketahui.

Diagram bar untuk memodelkan situasi pemberian koleksi pin tersebut adalah sebagai berikut.

Sebelum 


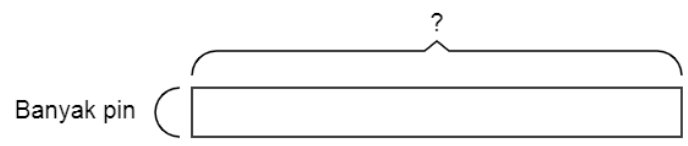

Sesudah

Banyak pin

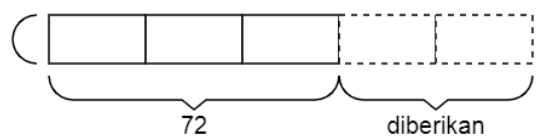

Perhitungan:

Pada situasi sesudah dapat diketahui bahwa tiga unit bar menyatakan sisa sebanyak 72 pin. Satu unit bar menyatakan $72 \div 3=24$ pin.

Karena satu unit bar menyatakan 24 pin maka dua unit bar menyatakan $2 \times 24=48$ pin yang diberikan.

Mengecek dan menafsirkan hasil:

Total banyak pin adalah $72+48=120$ pin.

Banyak pin diberikan ke Ovi adalah $\frac{2}{5} \times 120=48$ pin.

Dengan demikian Sekar memberikan 48 pin bros kepada Ovi.

\section{Soal cerita 5:}

Dirga mempunyai dua adik, Era dan Adib. Dirga memberikan $\frac{1}{6}$ dari permennya kepada Era dan $\frac{2}{5}$ dari sisanya kepada Adib. Pada akhirnya terdapat 12 permen yang dipunyai Dirga. Berapa banyak permen Dirga mula-mula?

Tahapan pemecahan masalah:

Memahami masalah:

Sebanyak $\frac{1}{6}$ dari permen Dirga mula-mula diberikan kepada Era. Terdapat permen tersisa. Sebanyak $\frac{2}{5}$ dari permen tersisa ini diberikan kepada Adib. Permen tersisa yang dipunyai Dirga sebanyak 12.

Merencanakan strategi:

Strategi pemecahan masalah yang akan digunakan adalah membuat diagram bar.

Melaksanakan strategi:

Masalah ini merupakan masalah sebelum-sesudah dengan kondisi akhir diketahui dan terdiri dari dua situasi sesudah.

Diagram bar untuk memodelkan situasi pemberian permen tersebut adalah sebagai berikut.

Sebelum

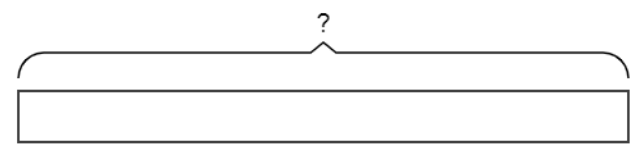

Sesudah (1)

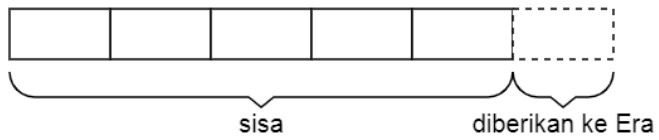


Sesudah (2)

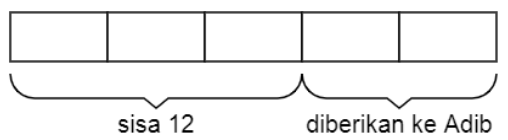

Perhitungan:

Pada situasi sesudah (2) dapat diketahui bahwa tiga unit bar menyatakan sisa sebanyak 12 permen. Satu unit bar menyatakan $12 \div 3=4$ permen.

Pada situasi sesudah (1) terdapat enam unit bar (termasuk satu unit bar bergaris putusputus). Karena satu unit bar menyatakan 4 permen maka enam unit bar menyatakan $6 \times 4=24$ permen

\section{Mengecek dan menafsirkan hasil:}

Banyak permen diberikan ke Era adalah $\frac{1}{6} \times 24=4$ permen.

Sebanyak $\frac{2}{5}$ dari sisa permen diberikan ke Adib. Yaitu $\frac{2}{5} \times(24-4)=\frac{2}{5} \times 20=8$ permen yang diterima Adib.

Sisa permen Dirga sebanyak 12 buah.

$4+8+12=24$ permen, cocok.

Dengan demikian Dirga mula-mula mempunyai 24 permen.

Berdasarkan beberapa contoh soal cerita di atas dan tahapan pemecahan masalahnya, terdapat beberapa hal penting terkait penggunaan strategi membuat diagram bar, yaitu:

(1) Panjang bar harus dibuat cukup proporsional antara satu bar dan bar yang lain. Hal ini untuk memperjelas hubungan antar kuantitas.

(2) Informasi yang diketahui nilainya dicantumkan pada bar, sedangkan informasi yang tidak diketahui nilainya dinyatakan dengan tanda tanya (?) yang dicantumkan pada bar. Hal ini untuk menunjukkan langkah komputasi yang harus dilakukan untuk menentukan nilai dari informasi yang tidak diketahui.

(3) Beberapa bar dengan jenis garis putus-putus atau bar yang diarsir diperlukan ketika terdapat bar yang perlu memperoleh penekanan.

Metode diagram bar dapat dikenalkan sebelum siswa mempelajari penyelesaian soal cerita dengan cara aljabar karena representasi visual dari diagram bar menjadikan masalah mudah untuk dipahami.

Kesulitan yang terjadi dalam penggunaan diagram bar adalah kesulitan membuat bar yang akurat apabila digambar secara manual dengan tangan (Cheong, 2002). Pembuatan bar yang akurat dalam hal ini tidak harus digambar dengan skala yang tepat, akan tetapi bar harus dibuat cukup proporsional sedemikian hingga dapat bermakna dalam penarikan kesimpulan terkait hubungan antara kuantitas yang diketahui dan tidak diketahui. Satu media teknologi informasi dan komunikasi (TIK) yang dapat digunakan untuk membantu membuat diagram bar secara akurat adalah Bar Modelling, salah satu media virtual manipulatives yang dapat dijalankan secara daring dari laman https://mathsbot.com/manipulativeMenu. 


\section{Kesimpulan}

Salah satu strategi pemecahan masalah yang perlu mendapat perhatian khusus adalah membuat diagram. Membuat diagram disarankan sebagai langkah awal dalam memahami masalah. Model diagram bar merupakan satu bentuk representasi diagram yang dapat membantu siswa menyelesaikan soal cerita. Penggunaan diagram bar dalam menyelesaikan soal cerita dapat menjadi strategi bagi siswa untuk menjembatani transisi dari memahami masalah dan membuat ekspresi matematis. Terdapat tiga struktur berbeda dalam metode model dengan diagram bar, yaitu bagian-keseluruhan (part-whole), perbandingan (comparison), dan situasi sebelum-sesudah (before-after). Langkah-langkah metode model dengan diagram bar memfasilitasi proses pemecahan masalah yang disarankan Polya. Metode diagram bar dapat dikenalkan sebelum siswa mempelajari penyelesaian soal cerita dengan cara aljabar karena representasi visual dari diagram bar menjadikan masalah mudah untuk dipahami.

Penelitian lebih lanjut tentang penggunaan metode diagram bar untuk menyelesaikan soal cerita masih sangat terbuka untuk dilakukan. Misalnya terkait keefektifan penggunaan metode ini dalam penyelesaian soal cerita pada siswa jenjang SD atau SMP.

\section{Daftar Pustaka}

Ballew, Hunter dan James W. Cunningham. (1982). Diagnosing strengths and weaknesses of sixthgrade students in solving word problems. Journal for Research in Mathematics Educations Volume 13 No. 3, pp. 202-210.

Beckmann, Sybilla. (2004). Solving algebra and other story problems with simple diagrams: a method demonstrated in grade 4-6 texts used in Singapore. The Mathematics Educator Volume 14 No. 1, pp. 42-46.

Cheng, Lu Pien. (2015). Error analysis for arithmetic word problems: a case study of primary three students in one Singapore school. International Journal for Mathematics Teaching and Learning, pp. 1-27.

Cheong, Yan Kow. (2002). The model method in Singapore. The Mathematics Educator Volume 6 No. 2, pp. 47-64.

Clarke, Laura. (2017). Singapore bar models appear to be the answer, but what then was the question? Proceeding British Society for Research into Learning Mathematics 37(2).

Englard, Lisa. (2010). Raise the bar on problem solving. Teaching Children Mathematics, pp. 156165.

Fong, Ng Swee. (2003). How secondary two express stream students used algebra and the model method to solve problems. The Mathematics Educator Volume 7 No. 1, pp. 1-17.

Fong, Ng Swee. (2004). Developing algebraic thinking in early grades: case study of the Singapore primary mathematics curriculum. The Mathematics Educator Volume 8 No. 1, pp. 39-59.

Fong, Ng Swee dan Kerry Lee. (2005). How primary five pupils use the model method to solve word problems. The Mathematics Educator Volume 9 No. 1, pp. 60-83.

Fong, Ng Swee dan Kerry Lee. (2008). As long as the drawing is logical, size does not matter. The Korean Journal of Thinking and Problems Solving Volume 18 No. 1, pp. 67-82.

Fong, Ng Swee dan Kerry Lee. (2009). Model method: a visual tool to support algebra word problem solving at the primary level, dalam Wong Khoon Yoong, Lee Peng Yee, Berinderjeet Kaur, dkk (Ed), Mathematics Education: The Singapore Journey. Singapore: World Scientific Publishing Co. Pte. Ltd.

Gani, Maimunah Abdul, Khairul Amilin Tengah, dan Hardimah Said. (2019). Bar model as intervention in solving word problem involving percentage. International Journal on Emerging Mathematics Education Volume 3 No. 1, pp. 69-76. 
Garzon, Julius R. dan Leomarich F. Casinillo. (2021). Visualizing mathematics: the use of block models for strategic problem solving. Journal of Educational Research and Evaluation Volume 5 Issue 1, pp. 112-117.

Har, Yeap Ban. (2015). Bar Modeling, A Problem Solving Tool: From Research to Practice, An Effective Singapore Math Strategy. Singapore: Marshall Cavendish Education Pte. Ltd.

Hoe, Lee Ngan, Koay Phong Lee, Charlotte Collars, dkk. 2020. Shapping Maths: Coursebook 2B-6B. Singapore: Marshall Cavendish Education Pte. Ltd.

Hofer, Claire. (2015). The introduction of the Singapore bar model in year 1 problem solving: a personal reflection. The STeP Journal Volume 2 No. 1, pp. 107-117.

Huat, Juliana Ng Chye dan Lim Kian Huat. (2005). A Handbook for Mathematics Teachers in Primary Schools of Singapore. Singapore: Federal-Marshall Cavendish Education.

Kaur, Berinderjeet. (2015). The model method: a tool for representing and visualizing relationships. Proceeding ICMI Study 23: Primary Mathematics Study on Whole Numbers, pp. 448-455.

Khng, Kiat Hui dan Kerry Lee. (2009). Children's strategy choice and success in solving algebra word problems: interplay between cognitive variables and knowledge. Proceeding $3^{r d}$ Redesigning Pedagogy International Conference.

Kho, Tek Hong, Yeo Shu Mei, dan James Lim. (2009). The Singapore Model Method for Learning Mathematics. Singapore: EPB Pan Pacific.

Kho, Tek Hong, Shu Mei Yeo, dan Fan Lianghuo. (2014). Model method in Singapore primary mathematics textbooks. Proceeding International Conference on Mathematics Textbook Research and Development.

NCTM. (2000). Principles and Standars for School Mathematics. Reston, VA: National Council of Teacher of Mathematics (NCTM).

Polya, George. (2004). How to Solve It: A New Aspect of Mathematical Method. Princeton: Princeton University Press.

Puteh, Marzita, Nor'ain Mohd Tajudin, Mazlini Adnan, dan Azrul Azwan Mohd Abdul Aziz. (2017). The utilization of bar model method in year 5 mathematics learning based on HOTS. International Journal of Advanced Biotechnology and Research Volume 8 Special Issue 3, pp. 56-63.

Reed, Stephen K. (1999). Word Problems: Research and Curriculum Reform. Mahwah, NJ: Lawrence Erlbaum Associates Publishers, Inc.

Spencer, Ruth dan Helen Fielding. (2015). Using the Singapore bar model to support the interpretation and understanding of word problems in key stage 2. Proceeding British Society for Research into Learning Mathematics 35(3).

Thirunavukkarasu, M. dan S. Senthilnathan. (2014). Effectiveness of bar model in enhancing the learning of mathematics at primary level. International Journal of Teacher Educational Research Volume 3 No. 1, pp. 15-22.

Thirunavukkarasu, M. dan S. Senthilnathan. (2017). Effectiveness of bar model in teaching algebra at secondary level. International Journal of Teacher Educational Research Volume 6 No. 1012, pp. 34-43.

Wuan, Lee Yee, Leong May Kuon, dan Low Wai Cheng. (2004). Exploring Mathematics $1 A$. Singapore: EPB Pan Pacific.

aYee, Lee Peng dan Lee Ngan Hoe. (2009). Teaching Primary School Mathematics: A Resource Book. Singapore: McGraw-Hill Education (Asia).

bYee, Lee Peng dan Lee Ngan Hoe. (2009). Teaching Secondary School Mathematics: A Resource Book. Singapore: McGraw-Hill Education (Asia).

Yeo, Joseph B. W., Ban Heng Choy, Li Gek Pearlyn, dkk. (2019). Innovative pedagogical practices, dalam Tin Lam Toh, Berinderjeet Kaur, dan Eng Guan Tay (Ed), Mathematics Education in Singapore. Singapore: Springer Nature Singapore Pte. Ltd.

https://mathsbot.com/manipulativeMenu. 